\title{
Horticulture Research In Central Asia: A review of Papers from Scopus Database Published for The Period of 2000-2020
}

\author{
Abdullaev Sadulla Abdullaevich ${ }^{1}$, Rajametov Sherzod Nigmatullaevich ${ }^{2 *}$
}

\begin{abstract}
Authors' affiliation
${ }^{1}$ Center of Genomics and bioinformatics, Academy of Science of Uzbekistan, Tashkent, Uzbekistan

${ }^{2}$ Center for implementation of foreign investment projects in water sector under Ministry of water resources of the Republic of Uzbekistan *Corresponding author email: sherzod_2004@list.ru
\end{abstract}

\begin{abstract}
Horticulture crops (fruit trees) had been grown and cultivated from ancient times in Central Asia. Few researchers have addressed the problem of this profitable sector in the former Great Silk Road, which was at the crossroads of trading avenues. Horticulture has received much attention in the last twenty years. To investigate the current state of research activity of horticulture in Central Asia, we downloaded 4205 English papers from the Scopus database between 2000-2020. We identified a total of 50 papers, and the last four years have witnessed significant growth in publication number, an average of 5 articles per year. Acta Horticulturea was one of the most productive journal. Institute of Plant Biology and Biotechnology (Almaty) and the Academy of Sciences of the Republic of Uzbekistan have worked productively to study high issues. United States Department of Agriculture and Swiss National Science Foundation with Karl Popper Foundation have supported scientific activity in the region. Top 15 highly cited articles were published within the framework of funded projects with international researchers. Researchers of Central Asia focused on walnut, grape and apple, studied on molecular level and cryopreservation of wild relatives for future use. Cherry, apricot, almond and pomegranate crops were less studied by researchers.
\end{abstract}

\section{Keywords: (4-5, separate with comma) horticulture, Central Asia, bibliometric analyses, science.}

\section{Introduction}

Horticulture is the art and science of growing fruits, vegetables, herbs, nuts, and ornamental crops and terminology which has a Latin root, "hortus" means garden and "colere" to culture (trees, shrubs, flowering plants, and turf) (Gan and Xue, 2021; Kolle et al., 2017). Pomology (fruit cultivation), market gardening (vegetable and herb cultivation), and ornamental cultivation (flowers, shrubs, trees) are the main horticulture areas. In turn, ornamental crops have two sub-groups arboriculture (woody plants) and floristry. Nut and grape crops are a small division of horticulture (Arteca, 2015).

Horticultural crops have been grown for millennia in assuring their survival for the future (Goldschmidt, 2013). Horticulture crops were studied by human society, that, conducted many research methodologies to domesticate and introduced horticulture crops for their local areas from other countries (Diamond, 2002; Presniakova, et al., 2020). Some complex measures are applied to domesticate and cultivate horticulture crops e.g. breeding, fertilization, plant protection, irrigation, harvesting (Yang and Xu, 2021). Nowadays, this complexity has been solved based on scientific advanced technologies, as biotechnology, genetics, omics subjects, and bioinformatics (Arteca, 2015; Chen et al., 2019; Igarashi et al., 2016; Martínez-García, et al., 2020a; Martínez-Gómez et al., 2021b; Velasco et al., 2010; Yu et al., 2020; Zhou et al., 2017).

Horticulture crops have become more domesticated and commonly cultivated in Central Asia (Mirzaev et al., 2004; Tashmatov et al., 2000). The territory of this region occupies approximately four million square kilometers (Lapelia et al., 2014). This region is well-known as one of the original centers of horticulture crops, as Malus domestica- (apple), Armeniaca vulgaris (apricot), Persica vulgaris (peach), Pyrus communis (pear), Prunus domestica (plum), Vitis vinifera (grape), Amygdalus communis (almond), Juglans regia (walnut), Pistacia vera (pistachio), Punica granatum (pomegranate), and Ficus corica (Figure) (Asian Development Bank, 2019; Babu and Djalalov, 2006; Mapelli et al., 2011; Mirzaev et al., 2004; Smale, 2005; Sottile et al., 2014). N.Vavilov in 1930 found some wild apples (Malus sieversii) in Central Asia and informed that Central Asia is a center of origin for the domesticated apple (Janick, 2003). Kyrgyzstan, Tajikistan, and Uzbekistan have a large territory of walnut trees, and the region is known as one of the original centers the horticulture crops (Mapelli et al., 2011). For instance, in Kyrgyzstan, walnut forest covers approximately 47000 hectares, 1.17\% percent of the total $4003451 \mathrm{~km}^{2}$ Central Asian territories (Rehnus, et al., 2013). On the other hand, while walnut has occupied a large territory, the coefficient of productivity is in a critical condition (Müller and Sorg, 2001; Scheuber et al., 2000). 
During the Soviet Union, Central Asia was a centrally planned economy that cultivated mainly cotton crops (van Berkum, 2015). The research activity in Central Asia has been organized based on governmental financial support (Babu and Djalalov, 2006; Smale, 2005). For several years, agriculture faced an economic crisis, and this condition sparked in the first period of independence when the gross domestic product (GDP) contributed from agriculture approximately 10-46\% (Babu and Djalalov, 2006; Yu et al., 2020). For the past five years, there has been a rapid rise in the trade of horticulture in Central Asia. For instance, in 2018 only, the export of horticulture crops accounted for approximately $\$ 108.8$ million to Russia, and between 2015 - 2017 exported a total of $\$ 1.5$ billion fruits to China, Central Asia (\$415.5 million) has a significant advantage (World Bank, 2020).

Bibliometric analysis is a clear assessment that shows the state of the quality and number of scientific articles (Zyoud, et al., 2014). Bibliometric analysis includes the number of authors, papers, citations, type of papers, collaboration with international scientists, foundations (inner/outer), institutes/organizations (Zhu and Liu, 2020; Zyoud et al., 2014). A few researchers have addressed the horticulture of Central Asian biodiversity, climate change, walnut forest, Central Asian agriculture trend, export potential of the region, wild relatives of apples, almond, apricot, and their conservation methods, cultivation of seedless grapes, and economic state by a view of World Bank and so on (Asian Development Bank, 2019; Batsaikhan and Dabrowski, 2017; Cantarello et al. 2014; Janick, 2003; Kovalchuk et al., 2017d; Lapelia and Programa, 2014; Mamadjanov, 2005; Mirzaev et al., 2004; Rahmani et al., 2015; Rehnus et al., 2013; Romadanova et al., 2016; Sottile et al., 2014; van Berkum, 2015; World Bank, 2020; Zaurov et al., 2013). Central Asian horticulture research is currently a less studied topic. This paper is a review of a preliminary attempt to estimate bibliometric analysis of Central Asian horticulture (pomology) articles published in Scopus journals in English. We reviewed the number of papers, journals, top authors, institutions, international funds and researchers collaborated on horticulture issue in Central Asia between 2000 and 2020.

\section{Materials and Methods}

To verify the research activities in the field of horticulture in Central Asia, we selected a subject area of Agricultural and Biological Sciences (4205 papers) from the Scopus database between 2000 and 2020. We focused only on pomology (fruit trees) upon reviewing the current state of research activity in Central Asia. All papers were analyzed and reviewed using "horticulture", "viticulture", "Vitis", "in vitro", "micro- propagation", and "genetic resources" as the keywords. A total of 50 Central Asian papers were sorted out for the future analysis of horticulture issues which is shown in Figure 1. We used VOS viewer to visualize the bibliometric data, including top authors, keywords used in abstract, and titles (van Eck and Waltman, 2021).

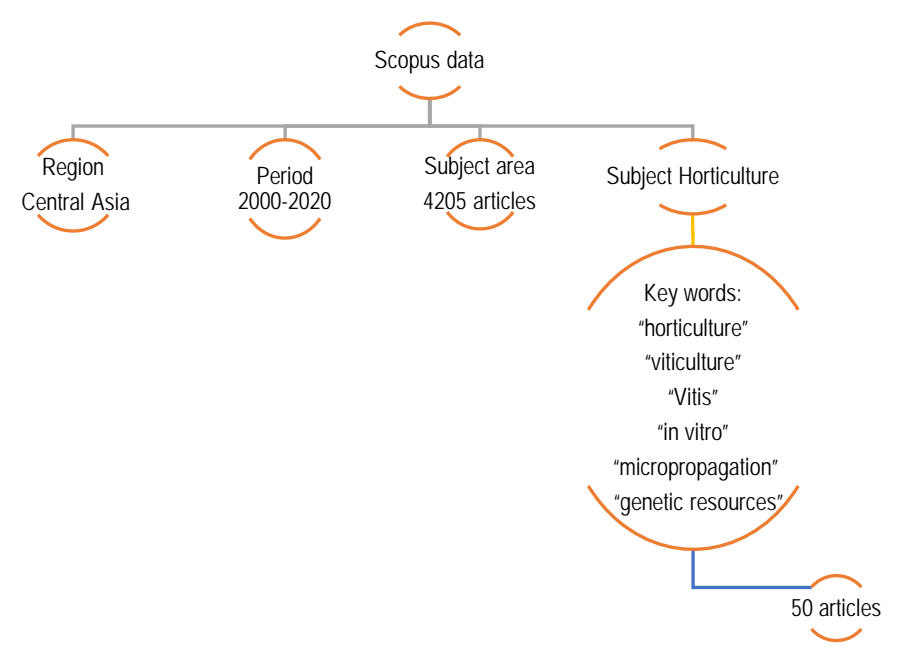

Figure 1. The search strategy of data.

\section{Results and Discussion}

3.1. Published papers on horticulture research in Central Asia. We categorized horticulture papers as follows, the paper numbers, authors, and pages per paper between 2000-2020. These analyses revealed that the number of papers (NP), authors of papers (AP), the number of authors per paper (NAP), pages of per papers (PP), the number of references (NR) in the Scopus category of related topic increased gradually. Central Asian researchers were more interested in the horticulture topic, as seen in Table 1. Almost $28 \%$ of the total number of articles were published by 64 authors out of 227 . The most remarkable finding from the data is 
Page 3 of 14

that after 2013, the number of publications in the Scopus category journals doubled, and six horticulture papers were published. We observed that for the Central Asia region during the 2002, 2005, 2007, 2009, 2010, 2012 there were no articles published on horticulture issue.

Table 1. Characteristics of Central Asian Horticulture articles in the Scopus journals of (2000-2020)

\begin{tabular}{|c|c|c|c|c|c|c|}
\hline & NP & AP & NAP & PP & NR & Year \\
\hline & 1 & 7 & 7,0 & 5 & 7 & 2000 \\
\hline & 1 & 1 & 1,0 & 14 & 38 & 2001 \\
\hline & 2 & 8 & 4,0 & 12 & 24 & 2003 \\
\hline & 1 & 7 & 7,0 & 5 & 17 & 2004 \\
\hline & 3 & 10 & 3,3 & 27 & 21 & 2006 \\
\hline & 1 & 4 & 4,0 & 10 & 19 & 2009 \\
\hline & 2 & 10 & 5,0 & 13 & 21 & 2011 \\
\hline & 3 & 17 & 5,7 & 27 & 103 & 2013 \\
\hline & 6 & 25 & 4,2 & 67 & 196 & 2014 \\
\hline & 3 & 15 & 5,0 & 33 & 84 & 2015 \\
\hline & 4 & 20 & 5,0 & 34 & 95 & 2016 \\
\hline & 5 & 22 & 4,4 & 64 & 171 & 2017 \\
\hline & 2 & 5 & 2,5 & 18 & 66 & 2018 \\
\hline & 5 & 25 & 5,0 & 48 & 141 & 2019 \\
\hline & 11 & 51 & 4,6 & 103 & 225 & 2020 \\
\hline Total & 50 & 227 & 4.5 & 480 & 1228 & \\
\hline
\end{tabular}

NP- number of papers, AP- authors of papers, NA (AP/NP) - number of authors per paper, PP- page number of per papers, NRnumber of references.

3.2. Published articles of horticulture issue in Central Asia between 2000-2020. It is important to select the proper journal before submitting the manuscript. Figure 2 shows that before 2014, we found a small number of papers (13 papers), which accounts for nearly $26 \%$ of the total 50 articles. In 2014 there was a sharp increase the number of publications doubled up to 6 articles, whereas before the rate of article were 3 articles per year. The number of publications on horticulture topics fell off by $50 \%$ in 2015 compared to prior 2014. The record number of publications among the group was recorded in 2020 (frequency $=11$ ).

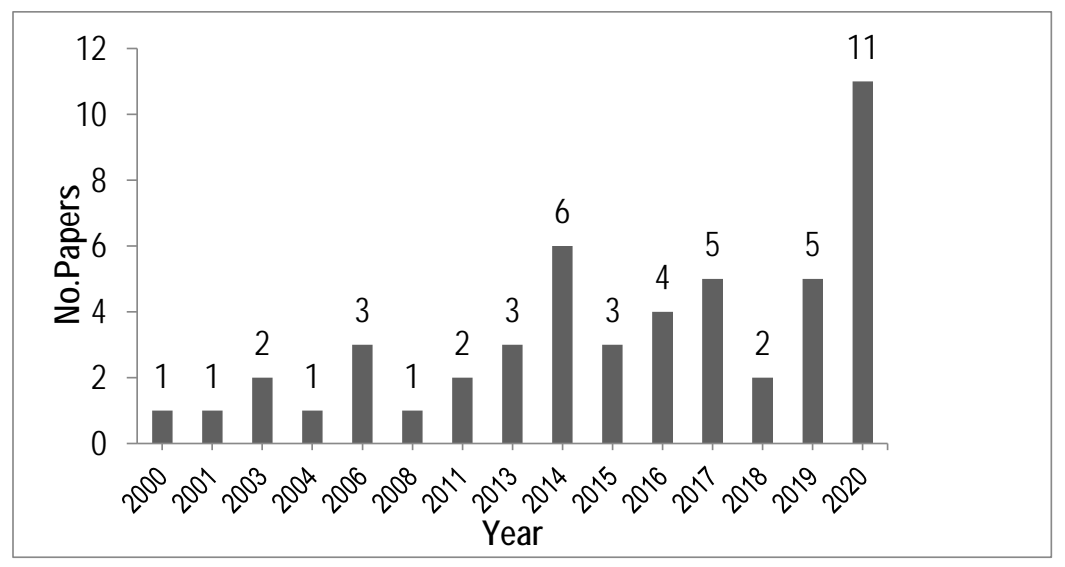

Figure 2. Number of articles with the horticulture topics arranged by the year of publication

Table 2. Journals appearing horticulture research topics between period 2000-2020.

\begin{tabular}{|c|c|c|l|c|c|}
\hline Journals & №.papers & $\%$ & Journals & №.papers & $\%$ \\
\hline Acta Horticulturae & 8 & 16 & $\begin{array}{l}\text { Journal of Applied Botany and } \\
\text { Food Quality }\end{array}$ & 1 & 2 \\
\hline
\end{tabular}




\begin{tabular}{|c|c|c|c|c|c|}
\hline $\begin{array}{l}\text { Chemistry of Natural } \\
\text { Compounds }\end{array}$ & 5 & 10 & Journal of Elementology & 1 & 2 \\
\hline Cryo-Letters & 3 & 6 & Journal of Forestry Research & 1 & 2 \\
\hline $\begin{array}{l}\text { Asian Journal of } \\
\text { Microbiology, }\end{array}$ & 2 & 4 & Journla Mountain Science & 1 & 2 \\
\hline $\begin{array}{l}\text { EurAsian Journal of } \\
\text { BioSciences }\end{array}$ & 2 & 4 & Journal of Plant Pathology & 1 & 2 \\
\hline HortScience & 2 & 4 & $\begin{array}{l}\text { Journal of Sustainable } \\
\text { Forestry }\end{array}$ & 1 & 2 \\
\hline $\begin{array}{l}\text { Acta Technologica } \\
\text { Agriculturae }\end{array}$ & 1 & 2 & Khimiya Rastitel'nogo Syr'ya & 1 & 2 \\
\hline $\begin{array}{l}\text { Agricultural Research } \\
\text { Updates }\end{array}$ & 1 & 2 & Plant Biotechnology Reports & 1 & 2 \\
\hline Agrochimica & 1 & 2 & $\begin{array}{l}\text { Plant Cell, Tissue and Organ } \\
\text { Culture }\end{array}$ & 1 & 2 \\
\hline Agroforestry Systems & 1 & 2 & Plant Methods & 1 & 2 \\
\hline $\begin{array}{l}\text { Annals of Agri Bio } \\
\text { Research }\end{array}$ & 1 & 2 & PLOS ONE & 1 & 2 \\
\hline $\begin{array}{l}\text { Australian Journal of } \\
\text { Crop Science }\end{array}$ & 1 & 2 & $\begin{array}{l}\text { Research for Rural } \\
\text { Development }\end{array}$ & 1 & 2 \\
\hline Biosciences BR Asia & 1 & 2 & Turczaninowia & 1 & 2 \\
\hline $\begin{array}{l}\text { Critical Reviews in Food } \\
\text { Science and Nutrition }\end{array}$ & 1 & 2 & $\begin{array}{l}\text { Valuing Crop Biodiversity: } \\
\text { On-Farm Genetic Resources } \\
\text { and Economic Change }\end{array}$ & 1 & 2 \\
\hline $\begin{array}{l}\text { European Food } \\
\text { Research and } \\
\text { Technology }\end{array}$ & 1 & 2 & Food Policy & 1 & 2 \\
\hline $\begin{array}{l}\text { Fresenius } \\
\text { Environmental Bulletin }\end{array}$ & 1 & 2 & $\begin{array}{l}\text { Forests Trees and } \\
\text { Livelihoods }\end{array}$ & 1 & 2 \\
\hline Genetica & 1 & 2 & $\begin{array}{l}\text { In Vitro Cellular and } \\
\text { Developmental Biology - Plan }\end{array}$ & 1 & 2 \\
\hline
\end{tabular}

Table 2 shows 34 journals that have published Central Asian horticulture research. To date, almost 28 journals have published at least one article on Central Asian horticultural problems. Some of the major journals were Journal of Acta Horticulturae, Chemistry of Natural Compounds, Asian Journal of Microbiology, EurAsian Journal of BioSciences, HortScience. Figure 3 shows that, "Acta Horticulturae" journal published nearly 16\% of the papers, followed by the "Chemistry of Natural Compounds" journal, which published five papers (Mamadjanov, 2005; Kovalchuk et al., 2017d; Mapelli et al., 2011; Romadanova et al., 2016; Kovalchuk et al., 2011a; Rajametov and Nurbekov, 2020a,b). "HortScience" journal publshed in horticulture topics from Central Asia, by 4\% (2 articles) between 2000 and 2015. The journal of "Chemistry of Natural Compounds" actively printed horticulture articles before 2016, over the last four years, one article was appeared in this Scopus journal. The last three years have witnessed the quality of the horticulture research, and journals like PLoS ONE, Plant Method with high CiteScore level published articles from Central Asia (El-Sharkawy et al., 2017; Zhang et al., 2020). 


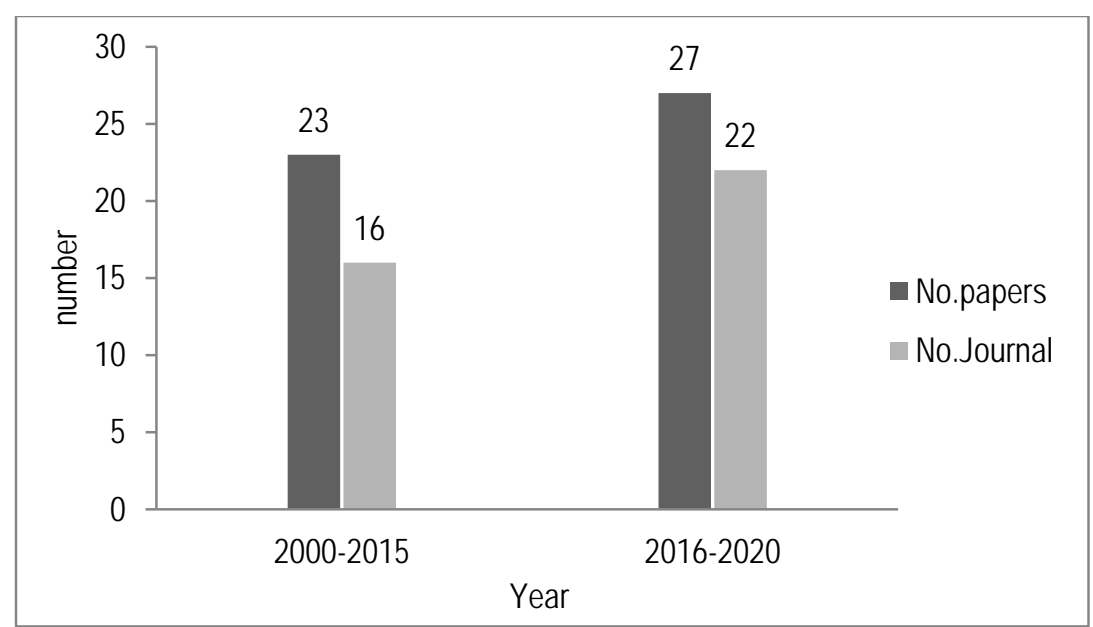

Figure 3. The trend of papers(1) and journals (2) numbers published horticulture topics in periods of 2000-2015 and 2016-2020

Figure 4 illustrates 14 most cited papers on Horticulture topic. Authors as Kovalchuk, Cantarello, Dalimov have a high level of citation among the group 40,17, and 14, respectively (Kovalchuk et al., 2009b; Cantarello et al., 2014; Dalimov et al., 2003). Kovalchuk I. focused on introducing biotechnology method to store apple germplasm and reported that in vitro storage of apple shoots were recommended by several researchers for one or two sorts only. They reported the first application to conserve the large number of apple genotypes by the example of Golden Delicious (Kovalchuk et al., 2009b). Biotechnology is becoming one of the powerful tools and nucleus of gene editing technologies, and this topic is attractive for scientists (Kovalchuk et al., 2009b; Tsvetkov et al., 1997; Zhou et al., 2017).

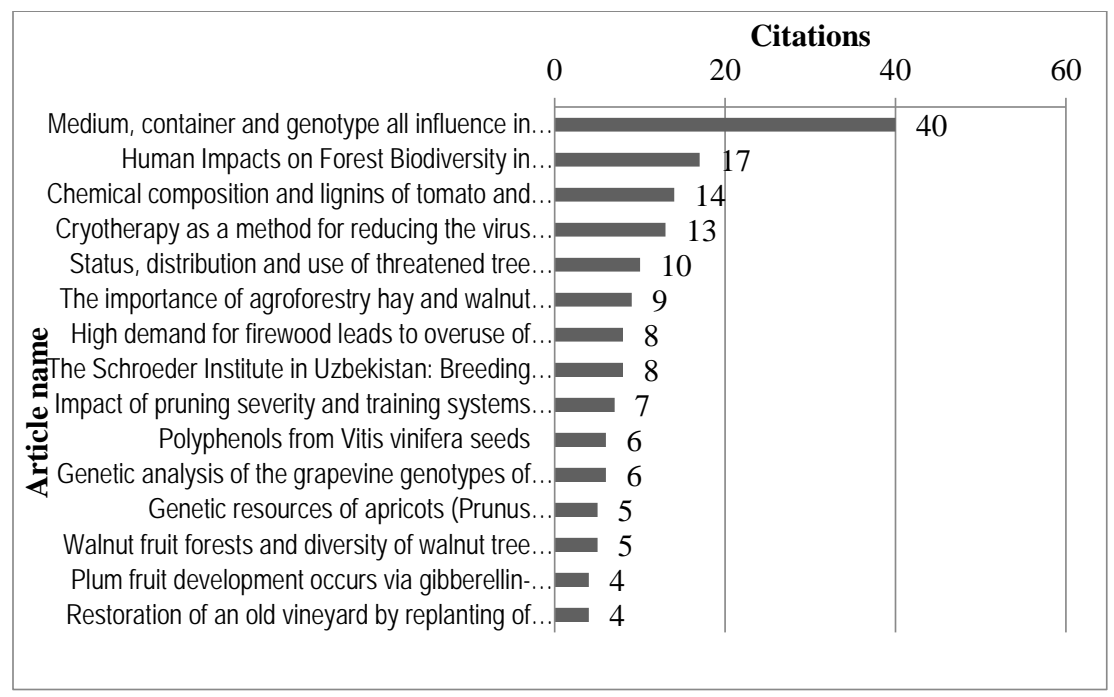

Figure 4. Top cited Central Asian horticulture articles published between 2000 and 2020 year

3.3. Top authors on horticulture in Central Asia. Authors play a critical part in the advancement of science or the development of a specific field. Figure 5 shows the top six writers who have collaborated with Central Asian researchers to study the horticulture issue. There is perfect interaction between authors, and between 2000-2020 total of 227 authors united in publishing 50 papers for horticulture problems in Central Asia. Out of the total of 50 articles, the response rate was $10 \%$ for Kovalchuk, as the first author. 
Page 6 of 14

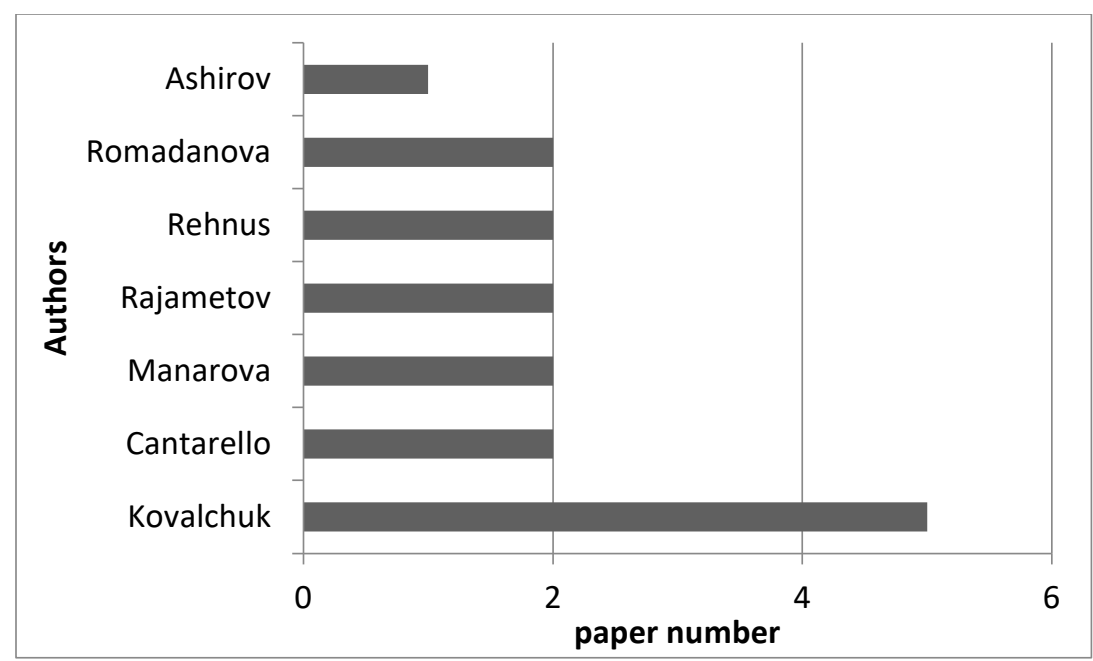

Figure 5. List of top authors published on horticulture issue in Central Asia

Figure 6 demonstrates the overlay visualization of VOS viewer for authors of horticulture topics. Nearly $1.32 \%$ of the papers published by the single authors, while the rest part published by two, three or more than four authors. Three authors (Asillbekova, 2001; Mamadjanov, 2005; Doolotkeldieva, 2018) published their papers as single author.

\section{fos vosviewer}

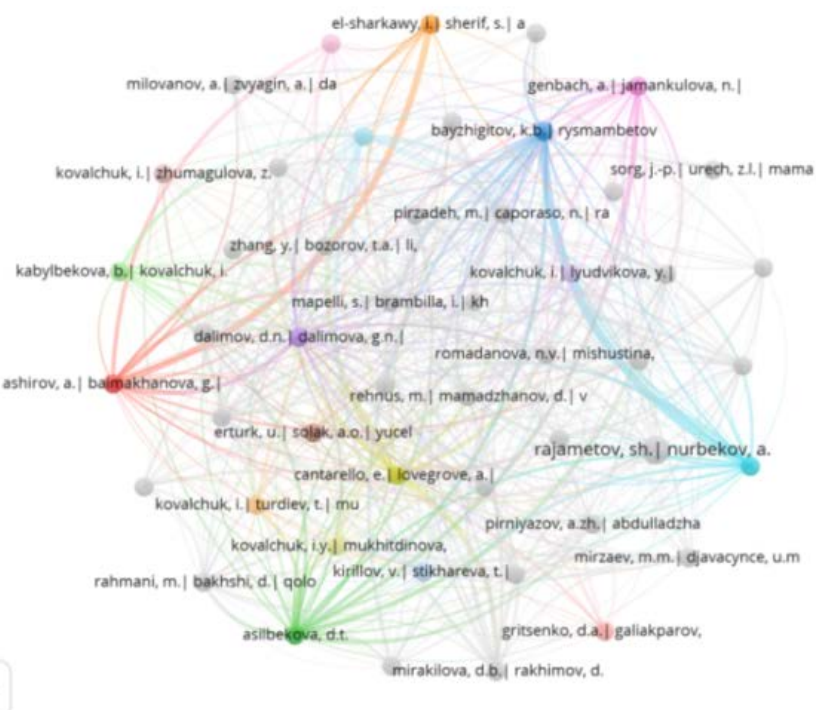

Figure 6. Visualization of authors and co-authors, a total of 50 horticulture articles published in 2000-2020

Figure 7 shows that Reed's cluster is the largest among the group and centralized in the center of visualization of VOS viewer. It informs that, Reed had more collaboration with Central Asian researchers to study horticulture issue. We found that, the interaction between authors and participants to study horticulture popularized after 2014 and reached its peak in 2020. A green Kowalchuk's cluster by VOS viewer linked several authors that had relationships with researchers in Central Asia between 2010 and 2014. For instance, Kovalchuk, Nasibulina and Reed published one article in 2011, in the case of that the color bar of Nasibulina A is green in overlay visualization of VOS viewer. The second cluster of VOS viewer had seven items (authors) included Kovalchuk, Madiyeva, Mukhitdinova, Reed, Turdiyev T, and the cluster of Reed owned the highest centrality by the network visualization of VOS viewer. 3.4. Research Institutes studied horticulture issue in Central Asia. A total of 50 horticulture research papers in Central Asia were written by 34 research organizations. Figure 8 shows that the Institute of Plant Biology and Biotechnology (IPBB-Almaty) was the group leader with a significant number of articles. The IPBB collaborated actively with the United States Department of Agriculture (USDA) and published nine articles out of ten with USDA. European Universities interested to study horticulture in Central Asia and Italian Universities of Palermo, Turin, Naples Federico II, and Pisa contributed actively with A. S. Sadykov Institute of Bioorganic Chemistry (Uzbekistan), University of Semey (Kazakhstan), Tashkent State Agrarian University. Over the past decade, 
we can see based on the Scopus database, that Central Asia collaborated with the institutions of UK, Russia, Jordan, Iran, Pakistan, Poland, Turkey, Bulgaria, and published several articles in collaboration. Kazakh National Agrarian University published two articles as single institution of publications about grape cultivars.

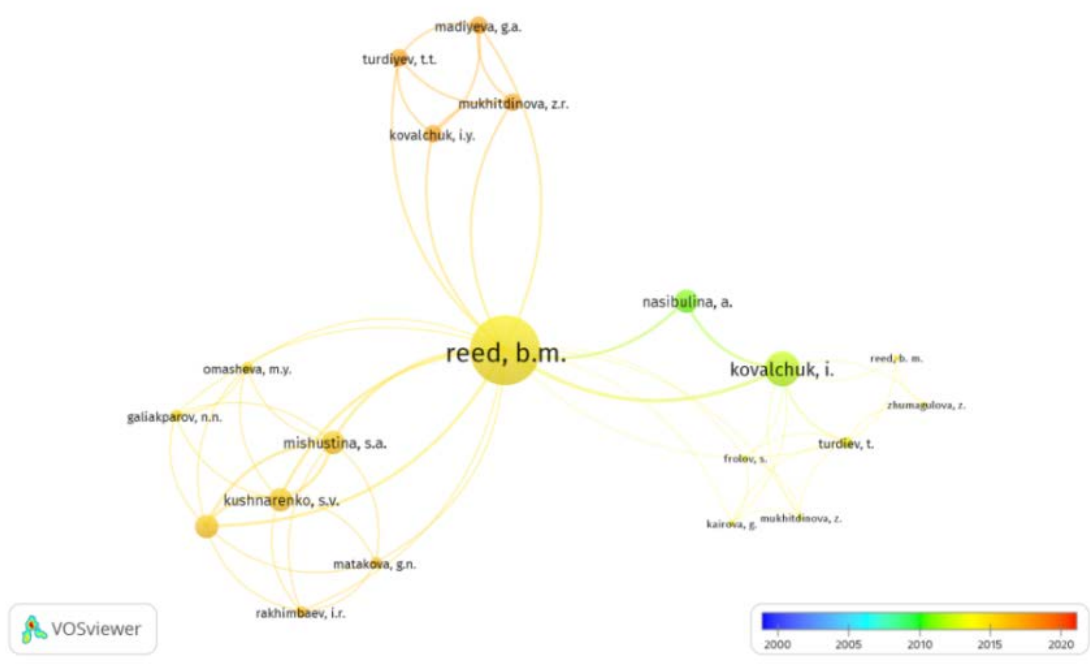

Figure 7. The network visualization of the most horticulture publishers based on the total number of articles. Note: minimum number of documents of an author 1 was applied for 227 authors. Of the 277 authors 102 meet the threshold and 20 items network connected to each other consisted of 3 items. The link size refers to the total number of articles, while line thickness and color refer to link strength and clustering, respectively.

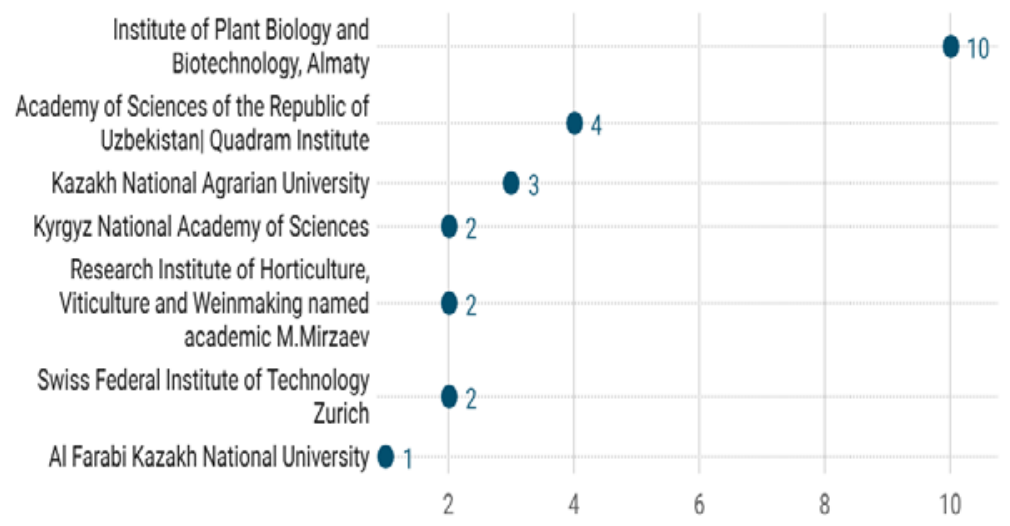

Figure 8. Central Asian organizations published horticulture research from 2000 to 2020 year

3.5. Funding agencies and countries supported horticulture study in Central Asia. In database of Scopus, we can see that, almost half of the top authors are not from Central Asian countries, but they have jointly published papers in a high-ranked journal. Collaboration with international researchers brought around $33(66 \%)$ papers out of 50 articles. The USA were most collaborated to study horticulture issue in Central Asia and leader among the group with 13 articles and followed European countries 12 articles, UK 4 articles, Italy and Switzerland by 3 articles, Germany and Finland by 1 article. Between 2000 and 2020, Kazakhstan pioneered with 21 horticulture papers in Central Asia, and 9 of them were in collaboration with the USA, by 1 article with UK, Finland, Germany, Bulgaria. Uzbekistan has also published 16 articles with countries such as United States - 10 articles, Italy, Russian Federation 3 articles, China, the UK, and with Kyrgyzstan - 1 article. There are several possible explanations for this situation. One of them is international funding that played a vital role in supporting a study of horticulture in Central Asia.

We found values for funding agencies of horticulture study in Central Asia and top 6 funding agencies list is given in Table 3. There was a significant positive impact of international funds on horticulture study in Central Asia. Further analyses indicated that just under USDA and Agricultural Research Service (ARS) Current Research Information Systems (CRIS) five high ranked papers were published in a collaboration of nine researchers from several countries. Other five articles were published by 
Page 8 of 14

supporting Swiss National Science Foundation, the Karl Popper Foundation, and the Vontobel Foundation "ORECH-LES's project. It is essential to highlight that Kazakhstan has been working productively with international funding organizations. Our investigation shows the importance of interaction in the development of horticulture in Central Asia.

Table 3. The list of top international organization funded horticulture study in Central Asia

\begin{tabular}{lccc}
\hline International Foundations & Authors & Journal & Citations \\
\hline & (Kovalchuk et al., 2017) & Acta Horticulturae & 3 \\
K428, USDA Agricultural Research Service & (Kovalchuk et al., 2014) & Cryo-Letters & 3 \\
CRIS 5358-21000-033D project & (Kovalchuk et al., 2009), & Plant Cell, Tissue and Organ & 40 \\
& (Kovalchuk et al., 2011) & Acta Horticulturae & 2 \\
& (Rehnus et al., 2013) & Journal of Forestry Research & 8 \\
& & Valuing Crop Biodiversity: & 3 \\
Swiss National Science & (Van Dusen et al., 2006) & On-Farm Genetic Resources & \\
$\begin{array}{l}\text { Foundation, the Karl Popper Foundation and } \\
\text { the Vontobel Foundation in the framework of } \\
\text { the project "ORECH-LES }\end{array}$ & and Economic Change & 9 \\
& (Rehnus et al., 2013) & Agroforestry Systems & 4 \\
$\begin{array}{l}\text { UK Darwin Initiative, Conserving } \\
\text { Eden: Participatory Forest Management in the }\end{array}$ & (Sorg et al., 2016) & Journal of Mountain Science & 4 \\
Tien Shan Region, 17001 & Journal of Sustainable & 17 \\
$\begin{array}{l}\text { Department of Agriculture Food Environment } \\
\text { (DAFE) of the, university of Pisa }\end{array}$ & (Orozumbekov et al., 2015) & Forests Trees and & 10 \\
\hline
\end{tabular}

3.6. Keywords Analysis, co-occurrence network. There are different keyword clusters available for the subject areas given in the Scopus database. Our findings would seem to show high-frequency keywords (Figure 9) using VOS viewer. Figure 9 (A and B) visualize three clusters of keywrods: first cluster includes four items (words), fatty acid, grape quality, variety, second cluster germplasm storage, micropropagation, Tajikistan, and the last was apple and walnut. Out of 164 key words 13 of them meet threshold and number of occurrences was set to 2 in VOSviewer. Further data collection has mapped on how keywords connect with one other. As seen in Figure 9 (A), the distance between the first and third clusters are closer to each other, and visualization illustrates the relation of the subject. To investigate the most used keywords, we also mapped using the title and abstract. In figure 9 (B) states an overlay visualization of horticulture study. From the title and abstract field have been extracted 1477 terms and divided into 11 clusters.

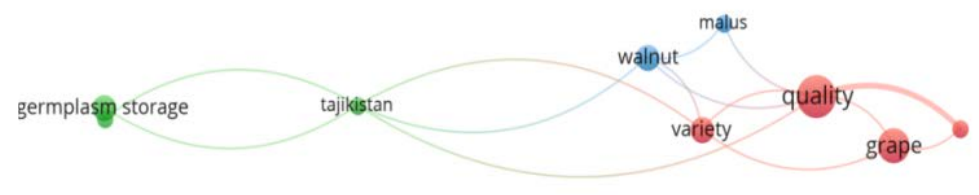


Figure 9 (A). Visualization of top terminus used in titles part of 50 papers. A co-occurrence network of keywords the most frequently appeared in Central Asian horticulture papers. Out of 164 key words 13 of them meet threshold and number of occurrences was set to 2 .

Figure 9 (B) illustrates that the keywords fruit (1st cluster includes the large items - 49), leaf, medium, growth, and walnut fruit forest are the most frequent and most discussed by central Asian researchers. The most striking result to emerge from the data is that the research activity of horticulture in Central Asia is beginning to introduce modern methods. It can be seen, that the word label of "Vitro culture" and "hepatoprotective activity" in overlay visualization disconnected with other labels, and it indicates a new research topic opportunity. In addition, the second cluster, which included forty-seven keywords, lists modern terminology as in micropropagation, Murashige and Skoog medium, in vitro cold storage, molecular SSR, and EST-SSR markers.

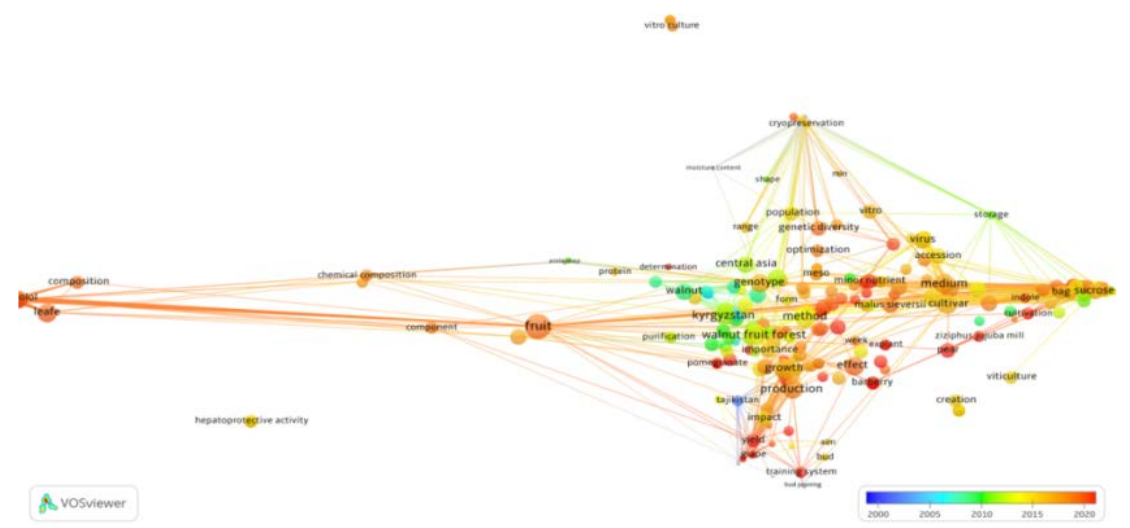

Figure 9 (B). Visualization of top terminus used in abstract and title part of 50 papers. Note: term of co-occurrence map constructed on the basis of text data and minimum number of co-currencies of a term was setting to 3 , number of term 1477, and 38 of them meet the threshold

We argue that our bibliographic analysis of Central Asian horticultural research may not cover and estimate the background and current status of the activity. Figure 10 demonstrated the most studied horticulture crops in Central Asia between 2000-2020. Horticulture has a deep background in Central Asia (Mirzaev, et al., 2004). The main reason for this facts are the variety of landscapes and climates of the region (Lapelia, et al. 2014). Central Asia locates in the heart of the Eurasian landmass, and it possesses unique importance for the plant's biodiversity (Asian Development Bank, 2019). According to some sources, once the Commonwealth of Independent States (CIS) got independence, horticulture crops received less focus than cotton and wheat (Tashmatov et al. 2000).

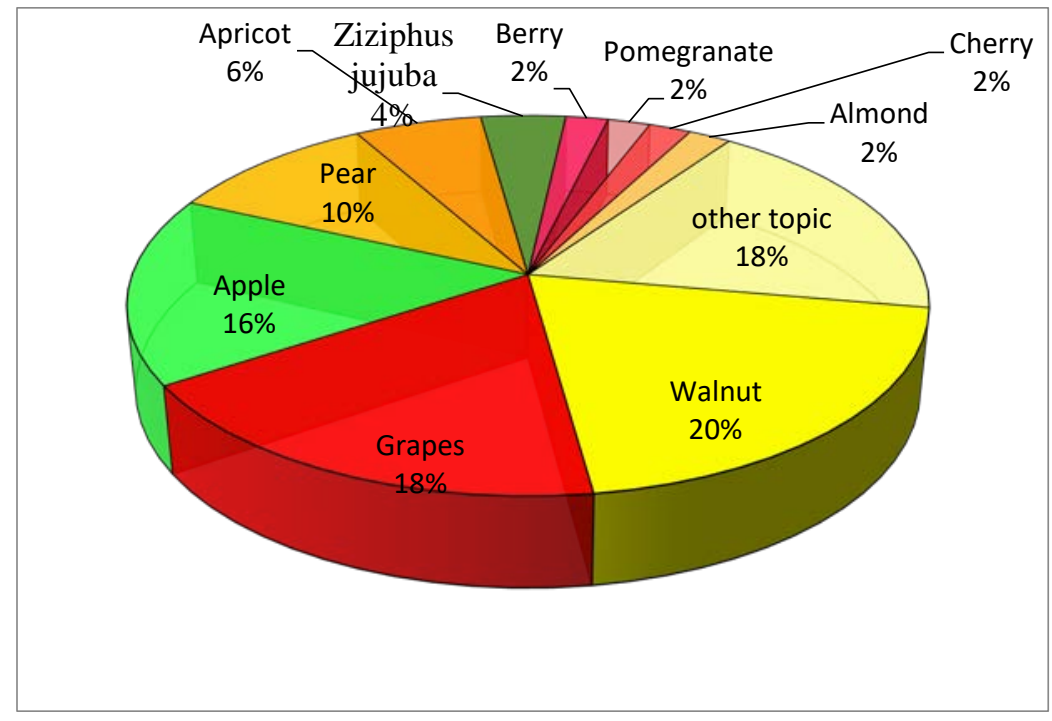


Page 10 of 14

Figure 10. The top horticulture crops conducted to research activity in Central Asia

Our downloaded papers inform that $\mathrm{CIS}$ made the most outstanding contribution to sustainable use and conservation of flora (Mirzaev, et al., 2004; Mamadjanov, 2005; Kovalchuk, et al., 2011a, Zaurov, et al., 2013; Rehnus, et al., 2013; Sottile, et al., 2014; Zhang, et al., 2020). There are several possible explanations for this result. Central Asia is one of the richest of specific and intraspecific diversity and some researchers reported a suitable protocol for long-term storage (cryopreservation) (Lapelia, et al., 2014; Kovalchuk et al., 2009b). Further analysis showed that biotechnological methods have been applied in horticulture significantly in Central Asia.

Walnut (Juglans regia) was the most frequent keyword, and the territory of walnut forests covers one-third of Central Asia. For instance, in the south of Kyrgyzstan, walnut covers approximately 631 000, and in Uzbekistan 4000 hectares. (Mamadjanov, 2005; Mapelli, et al., 2011; Rehnus, et al., 2013; Cantarello, et al., 2014; Orozumbekov, et al., 2015, Sorg, et al., 2016; Erturk, et al., 2020).

Grapes (Vitis vinifera) are most important and widely cultivated in Central Asia. On average, we found values for the breeding program of grapes, and the number of publications has significantly increased between 2014-2020. Moreover, the fact that potential interest increased on study introduced Vitis collection within a phenological and alternative genetic method using iBPS markers (Manarova, 2015). In addition, Gritsenko et al. (2018) utilized grapevine virus A (GVA) to design a specific vector. It is worthwhile noting that genetic engineering is applied simultaneously to the horticulture sector in Central Asia (El-Sharkawy, et al., 2017). In our view, the identification and characterization of horticulture crops based on genetics lead to a short breeding cycle and sustainable use of biodiversity. In pest management, for instance, this method could be used in plant protection, in virus test systems of plants, simplifying the requirements of plant quarantine agencies and increasing export potential (Chen, et al., 2019; Gan and Xue, 2021). In recent years, Kazakhstan has widely applied biotechnology and genetics to the grape industry (Zhambakin, et al., 2020)

Nowadays, the world market of grapes has changed some requirements for exporters, and seedlessness is one of the desirable futures for customers (Akkurt, et al., 2019). Unfortunately, scientific result of breeding program of seedless grapes was reported only in Tajikistan (Rahmani, et.al. 2015). In recent years breeding program of seedless grapes have been organized by the Center of Genomics and Bioinformatics (Uzbekistan) in collaboration with the National Research Institute Horticulture and Herbal Science (South Korea) (Figure 11). The embryo rescue method has been applied widely in a breeding program of seedless grapes (Akkurt et al. 2019). Embryo rescue is a reasonable solution for growing the hybrid population (Tsvetkov, et al., 1997).

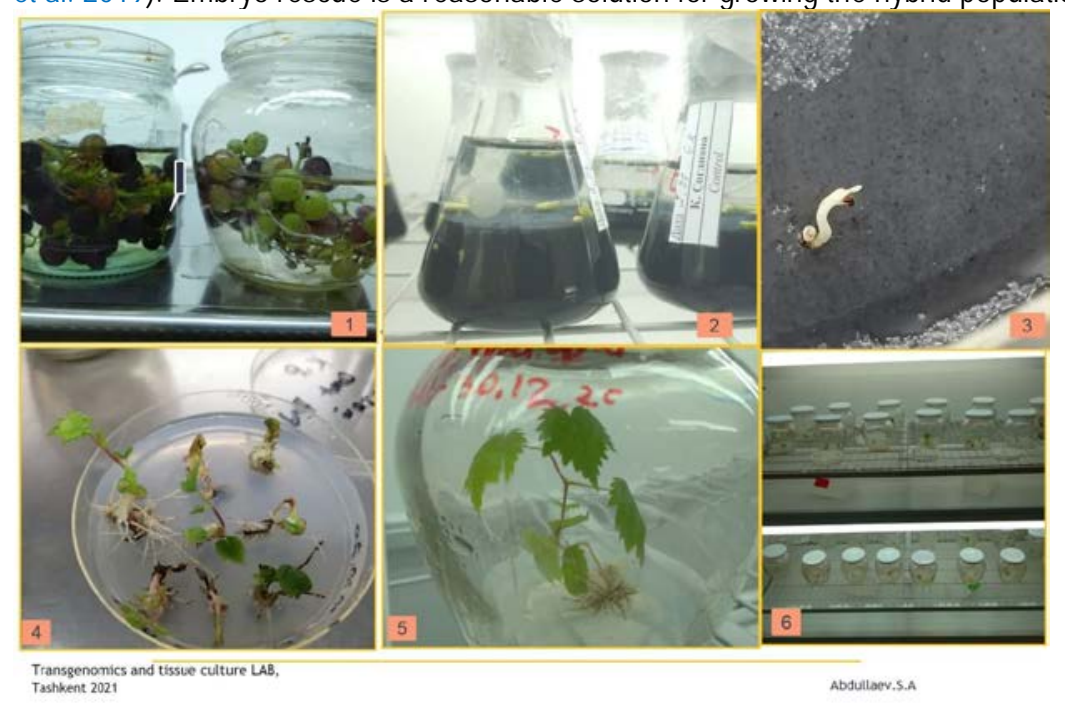

Figure 11. Breeding program of seedless grapes via embryo rescue method

Apple (Malus Miller) is the third frequently studied horticulture crop in Central Asia. One of the most pioneer organizations was the Institute of Plant Biology, and Biotechnology-Almaty. They focused to introduce biotechnological and genetical methods to study fruit trees as apples (Romadanova, et al., 2016; Romadanova, et al., 2017; Kabylbekova, 2020; Shadmanova, et al., 2019), plant protection in Kirgizstan (Doolotkeldieva, 2018), in vitro regeneration system Chinese researchers with Uzbekistan (Zhang, et al., 2020) and using paper bags in protecting apple fruits (Rajametov, et al., 2020) in Uzbekistan.

Central Asian countries produced cotton under the name "white gold" over the years (2 million tons), and Uzbekistan accounted for approximately 1.4 million tons (Gerts, et al., 2020). Considerable progress has been made with regard to study export potential of agriculture including horticulture of the region. They conclude that cherry, pears, almonds, pomegranates, apricot cultivars would 
Page 11 of 14

be a profitable industry for this region (van Berkum, 2015). According to some reports, the region has 8000 plant species and 83 of them are apricot varieties, 43 grapes, 40 apples, 30 walnuts, 21 pomegranates, and 15 pears. Well known that wild relives of crops the main source to develop (disease, stress factor, pest and virus) resistance verities and conserve food security (Chen, et al., 2019; Dempewolf, et al., 2017). Over the last years, Central Asian scientists have focused conservation of these crops in genetic banks and they have developed in vitro and cryopreservation methods (Kovalchuk, et al., 2011a, Turdiyev et al. 2020). Our findings would seem to show that time-consuming breeding programs were less organized research activity over the studied period (2000-2020).

4. Conclusion. We have presented between 2000 and 2020 , a total of 50 horticulture articles have published in 34 Scopus journals in Central Asia. Horticulture research activity came together with a total of 227 researchers, and the number of researchers has increased significantly from 2011, with an average of 21 authors per year. This work has revealed that, the number of publications on horticulture issue grew significantly from 2014, an average 5 articles per year. The list of Scopus category journals increased between 2016 and 2020, about 37\% (22) more journals than previous 2015 (16 journals). Out of 50 horticulture articles, $62 \%$ (31 articles) have got 189 citations, an average of 6 citations per article. The most productively studied on horticulture research in Central Asia were Institute of Plant Biology, and Biotechnology-Almaty (10 articles) and Academy of Science of Uzbekistan, Quarantine Institute (4 articles). The joint cooperation of authors illustrates a positive collaboration with international researchers all over the period. VOS viewer centralized Reed's item and the names of Kovalchuk, Frolov, Kairova, Mukhitdinova, Nasibulina, Turdiyev, Zhumagulova, connected under Reed's cluster. International funds impacted positively to study on horticulture issue of the region and USDA organized three projects to cryopreserve of apricot, pear and apple fruits. Taken together, these international funds might be proved important in developing horticulture for the enhancement of the conservation of Central Asian horticulture crops. We found that walnut forests were the most studied in Central Asia with an international team. They oriented to estimate of current status and developed some conservation methods of walnut forest in the region. Central Asian researchers applied biotechnology to propagation and cryopreservation of apples, apricot fruits. Finally, this picture of review informing us that international team upgraded research progress in Central Asia over the past decades.

\section{Acknowledgement}

The authors express their appreciation to the project "English for Science", implemented by the Ministry of Innovative Development of the Republic of Uzbekistan and PhD. Mukhiddin Juliev for the direction and inspiration for carrying out this reaserch. In addition, the authors are grateful to the anonymous reviewers of earlier drafts for constructive comments that helped to improve the manuscript.

\section{Conflict of interest}

The authors declare that they have no competing interests.

\section{ORCID ID authors}

0000-0002-3829-3107 (Abdullaev Sadulla Abdullaevich)

0000-0001-7055-9932 (Rajametov Sherzod Nigmatullaevich)

\section{References}

Akkurt, M., Tahmaz, H., Veziroğlu, S. (2019). Recent Developments in Seedless Grapevine. Breeding. South African Journal of Enology and Viticulture,40(2), 260-265. DOI:10.21548/40-2-3342

Arteca, R.N. (2015). Introduction to horticultural science, Second edition. Cengage Learning, Stamford, CT, 31.

Asian Development Bank. (2019). Agriculture Development in the Central Asia Regional Economic Cooperation Program Member Countries: Review of Trends, Challenges, and Opportunities. Asian Development Bank. Manila, Philippines, 8-33.

Asilbekova, D.T. (2001). Triacylglycerines of Ruta graveolens grown in vivo and in vitro. Chemistry of Natural Compounds, $37,5$. DOI:10.1023/A:1014498705342

Babu, S.C., Djalalov, S. (2006), Policy Reforms and Agriculture Development in Central Asia. Kluwer Academic Publishers, Boston, 45- 67.

Batsaikhan, U., Dabrowski, M. (2017). Central Asia - twenty-five years after the breakup of the USSR. Russian Journal of Economics, 3(3), 296-320. DOI:10.1016/j.ruje.2017.09.005

Cantarello, E., Lovegrove, A., Orozumbekov, A. (2014). Human Impacts on Forest Biodiversity in Protected Walnut-Fruit Forests in Kyrgyzstan. Journal of Sustainable Forestry, 33(5), 454-481. DOI:10.1080/10549811.2014.901918 
Page 12 of 14

Chen, F., Song, Y. and Li, X. (2019). Genome sequences of horticultural plants: past, present, and future. Horticulture Research, 6(1), 112-123. DOI:10.1038/s41438-019-0195-6

Dempewolf, H., Baute, G., Anderson, J. (2017). Past and Future Use of Wild Relatives in Crop Breeding. Crop Science, 57, 10701082. DOI:10.2135/cropsci2016.10.0885.

Diamond, J. (2002). Evolution, consequences and future of plant and animal domestication. Nature. 418(6898), $700-707$. DOI:10.1038/nature01019

Doolotkeldieva, T. (2018). Streptomyces bio-products against apple and pear diseases in organic orchards. Agricultural research updates volume (22), 42-83.

El-Sharkawy, I., Sherif, S., Abdulla, M., Jayasankar, S. (2017). Plum Fruit Development Occurs via Gibberellin-Sensitive and Insensitive DELLA Repressors. PLoS ONE, 12(1). DOI:10.1371/journal.pone.0169440

Erturk, U., Solak, A.O. \& Yucel. S. (2019). Determination of nut properties and chemical compositions of walnut (Juglans regia I.) genotypes grown in walnut-fruit forests of Kyrgyzstan. Fresenius Environmental Bulletin, 29(4A), 2809-2817.

Gan, S.S. \& Xue, H.W. (2021). Horticulture in a molecular age. Molecular Horticulture,1(1), 3.

Gerts, J., Juliev, M., Pulatov, A., (2020). Multi-temporal monitoring of cotton growth through the vegetation profile classification for Tashkent province, Uzbekistan. GeoScape, 14(62), 62- 69. DOI:10.2478/geosc-2020-0006

Goldschmidt, E.E. (2013). The Evolution of Fruit Tree Productivity: A Review. Economic Botany, 67(1), 51-62. DOI:10.1007/s12231-012-9219-y

Gritsenko, D.A., Galiakparov, N.N. (2017). Insertion of 2a self-cleaving peptides between orf4 and orf5 of grapevine virus a genome for vector development. Asian Journal of Microbiology, Biotechnology \& Environmental Sciences. 19(4), 10341040.

Igarashi, M., Hatsuyama, Y., Harada, T., Fukasawa-Akada, T. (2016). Biotechnology and apple breeding in Japan. Breeding Science, 66(1), 18-33.

Janick, J. (2003). Wild apple and fruit trees of Central Asia. Wiley, Hoboken, New Jersey., p. 15-58.

Joint, N. (2008). Bemused by bibliometrics: using citation analysis to evaluate research quality. Library Review, 57(5), 346-357

Kabylbekova B., Kovalchuk, I., Mukhitdinova , Z., Turdiyev, T., Kairova, G., Madiyeva, G. \& Reed, B. (2020). Reduced major minerals and increased minor nutrients improve micropropagation in three apple cultivars. In Vitro Cellular \& Developmental Biology: Plant; Heidelberg. 56(3), 335-349.

Kovalchuk, I., Nasibulina, A., Reed, B.M. (2011a). In vitro cold-storage duration of cherry shoots is affected by carbon source and nitrogen concentration. Acta Horticulturae, 918(20), 167-175.

Kovalchuk, I., Lyudvikova, Y., Volgina, M., Reed, B.M. (2009b). Medium, container and genotype all influence in vitro cold storage of apple germplasm. Plant Cell Tissue Organ Culture, 96(2), 127-136.

Kovalchuk, I., Turdiev, T., Mukhitdinova, Z., Frolov,S. \& Reed, B.M. (2014). Cryopreservation of native Kazakhstan apricot (Prunus armeniaca I) seeds and embryonic axes. Cryo Letters, 35(2), 83-93.

Kovalchuk, I.Y., Mukhitdinova, Z.R., Turdiyev, T.T. (2017d). Optimization of in vitro growth medium for a wild Kazakhstan apricot, Prunus armeniaca. Acta Horticulturae, 1155(27), 193-200.

Kolle, S.R., Shankarappa, T.H., Ho, Y.S. (2017). Highly Cited Articles in Science Citation Index Expanded - Subject Category of Horticulture: A Bibliometric Analysis. Erwerbs-Obstbau, 59(2), 133-145. DOI:10.1007/s10341-016-0308-4

Lapelia, I., Programa, N.M. (2014). Conservation of fruit tree diversity in Central Asia policy options and challenges. Biodiversity International, Rome. Global Environmental Facility, Biodiversity International, 5-42.

Mirzaev, M.M., Djavacynce, U.M., Zaurov, D.E. (2004). The Schroeder Institute in Uzbekistan: Breeding and Germplasm Collections. Horticulture Science, 39(5), 917-921. DOI:10.21273/HORTSCI.39.5.917

Mamadjanov, D.K. (2005). Walnut fruit forests and diversity of walnut tree (juglans regia I.) in Kyrgyzstan. Acta Horticulturae, 705(20), 173-176. DOI:10.17660/ActaHorticulturae.2005.705.20

Manarova, D.G., Kazybaeva, S.Z. (2015). Creation of New Competitive Grape Varieties with Different Ripening Times and With High Commercial and Gustatory Qualities Bred by the Kazakh Research Institute of Fruit Growing and Viticulture. Biosciences Biotechnology Research Asia, 12(2), 1197-1208. DOI:10.13005/bbra/1773

Mapelli, S., Brambilla, I., Khanazarov, A. (2011). Juglans regia in uzbekistan potential resource of biodiversity: trees and fruits description. Acta Horticulturae. 918, 835-842. DOI:10.17660/ActaHortic.2011.918.110 
Page 13 of 14

Martínez-Garcí, P.J., Hartung, J., Pérez, L., Cobos, F. (2020a). Temporal Response to Drought Stress in Several Prunus Rootstocks and Wild Species. Agronomy, 10(9), 1383-1393. DOl:10.3390/agronomy10091383

Martínez-Gómez, P. Rahimi, D, S., Salazar, J.A., López-Alcolea, J., Rubio, M. \& Martínez-García, P.J. (2021). Principles and Prospects of Prunus Cultivation in Greenhouse. Agronomy, 11(474), 2-15.

Müller, U., Sorg, J.P. (2001). Gestion multifonctionnelle des forêts de noyer du sud du Kyrgyzstan: tradition, problèmes actuels, perspectives, Multifunctional management of walnut-fruit forests in southern Kyrgyzstan: tradition, present situation, and perspectives. Schweizerische Zeitschrift fur Forstwesen, 152, 138-144.

Orozumbekov, A., Cantarello, E., Newton, A.C. (2015). Status, distribution and use of threatened tree species in the walnut-fruit forests of Kyrgyzstan. Forests, Trees and Livelihoods, 24(1), 1-17. DOI:10.1080/14728028.2014.928604

Presniakova, V.S., Farmanova, N.T., Turdieva, Z.V. (2020). Standardization of dry extract of ziziphus jujuba mill. FRUITS, 1, 329335. DOI:10.14258/jcprm.2020015220

Rahmani, M., Bakhshi, D., Qolov, M. (2015). Impact of pruning severity and training systems on red and white seedless table grape (Vitis vinifera) qualitative indices. Australian Journal of Crop Science. 9(1), 55 - 61

Rajametov, Sh., Nurbekov, A. (2020a). Effects of different types of paper bags on 'Carmen' pear fruits. Acta Horticulturae, 1275(46), 340-377. DOI:10.17660/ActaHorticulturae2020.1275.46

Rajametov, Sh., Nurbekov. A. (2020b). Effects of different types of paper bags on 'Golden Delicious' apple fruits. Acta Horticulturae, 1275(57), 415- 418. DOI:10.17660/ActaHorticulturae.2020.

Rehnus, M., Nazarek, A., Mamadzhanov, D. (2013). High demand for firewood leads to overuse of walnut-fruit forests in Kyrgyzstan. Journal of Forestry Research, 24, 797- 800. DOI:10.1007/s11676-013-0367-4.

Romadanova, N.V., Mishustina, S.A., Matakova, G.N., Kushnarenko, S.V., Rakhimbaev, I.R., \& Reed, B.M. (2016). In vitro collection methods for Malus shoot cultures used for developing a cryogenic bank in Kazakhstan. Acta Horticulturae, 1113(40), 271-277

Romadanova, N.V., Mishustina, S.A., Gritsenko, D.A., Omasheva, M.Y., Galiakparov, N.N., Reed, B.M \& Kushnarenko, S.V. (2016). Cryotherapy as a method for reducing the virus infection of apples (Malus sp.) Cryo Letters. 37(1):1-9

Sanmartin, C., Venturi, F., Taglieri, I., Ferroni, G., Scalabrelli, Narkabulova, N., Andrich, G. \& Zinnai, A. (2017). Restoration of an old vineyard by replanting of missing vines: effects on grape production and wine quality. Agrochimica, 61(2), 154-163

Scheuber, M., Köhl, M., Traub, B., (2000). Forstliche Inventur als Planungsgrundlage für die Forstwirtschaft Kirgistans | Planning Kyrgyzstan's Forestry on the Basis of Forest Inventories. Schweizerische Zeitschrift fur Forstwesen, 151, 75-79.

Shadenova, E.A. Mamirova, A.A. (2019). DNA extraction from leaves of woody plants without liquid nitrogen. Series of biological and medical, 1(331), 76-83.

Shadmanova, L., Sitpayeva, G., Mukanova, G., Friesen, N. (2019). Molecular-genetic analysis of Malus sieversii - comparison of Dzungarian populations in situ and ex situ, Turczaninowia. 22(2), 187-198.

Smale, M. (2005). Valuing crop biodiversity: on-farm genetic resources and economic change. CAB INTERNATIONAL, Wallingford, 336.

Sorg, J.P., Urech, Z.L., Mamadzhanov, D., Rehnus, M. (2016). Thinning effects on walnut stem and crown diameter growth and fruiting in the walnut-fruit forests of Kyrgyzstan. Journal of mountain science. 13(9), 1558-1566.

Sottile, F., Del Signore, M.B., Tsoy, M. (2014). Almond germplasm in bostanlyk area (Uzbekistan): preservation and exploitation. Acta Horticulturae, 1028, 303-306.

Tashmatov, A., Aknazarov, F., Juraev, A. (2000). Food policy reforms for sustainable agricultural development in Uzbekistan, the Kyrgyz Republic, and Tajikistan. Food Policy. 25(6), 719-732.

Tsvetkov, I., Tsolova, V., Atanassov, A. (1997). Genetic Transformation of Grape. Biotechnology Biotechnological Equipment. 11, 23-28. DOI:10.1080/13102818.1997.1081811

Turdieva, T.T., Kovalchuk, I., Kabylbekova, B.Z., Chukanova, N.I., Frolov, S. (2011). Conservation and sustainable use of biodiversity of fruit crops and wild fruit species proceedings of International scientific and practical conference, 23-26 August 2011, Tashkent, Uzbekistan. Biodiversity International, Rome. p.20.

Van Berkum, S. (2015) Agricultural potential and food security in Central Asia in the light of climate change, (95)1, 19-26.

Van Eck, N.J., Waltman, L. (2021). VOSviewer Manual. Leiden University.

Van Dusen, E., Dennis, E., llyasov, J., lee, M., Treche, S., \& Smale, M. (2006). Social institutions and seed systems: the diversity of fruits and nuts in Uzbekistan. CABI, FAO, and Bioversity International. Oxon, UK. 12,192-211 
Page 14 of 14

Velasco, R,. Zharkikh, A., Affourtit, J. (2010). The genome of the domesticated apple (Malus $\times$ domestica Borkh). Nature Genetics, 42(10), 833-839. DOI:10.1038/ng.654

World Bank. (2020). Central Asia's Horticulture Sector. World Bank, Washington, DC. 25p

Yang, B. \& Xu, Y. (2021). Applications of deep-learning approaches in horticultural research: a review. Horticulture Research, $8(1), 123-130$

Yu, X., Luo, H., Wang. H., Feil, J.H. (2020). Climate change and agricultural trade in central Asia: evidence from Kazakhstan. Ecosystem Health and Sustainability. 6(1), 2-13. DOI:10.1080/20964129.2020.1766380

Zaurov, D.E., Molnar, T.J., Eisenman, S.W. (2013). Genetic Resources of Apricots (Prunus armeniaca L) in Central Asia. Horticultural Science, 48(6), 681-691. DOI:10.21273/HORTSCI.48.6.68155

Zhang, Y., Bozorov, T.A., Li, D.X., (2020). An efficient in vitro regeneration system from different wild apple (Malus sieversii) explants. Plant Methods. 16(56), 2-10.

Zhambakin, K., Zhapar, K. (2020). Current status and prospects of plant biotechnology in Kazakhstan. Plant Biotechnol Rep. 14, 177-184

Zhou, Y., Massonnet, M., Sanjak, J.S. (2017). Evolutionary genomics of grape ( Vitis vinifera ssp. vinifera) domestication. Proceedings of the National Academy of Sciences of the United States of America, 114(44), 11715-11720. DOI:10.1073/pnas.1709257114

Zhu, J., Liu, W. (2020). A tale of two databases: the use of Web of Science and Scopus in academic papers. Scientometrics, 123(1), 321-335. DOI:10.1007/s11192-020-03387-8

Zyoud, S.H., Al-Jabi, S.W., Sweileh, W.M. (2014). Bibliometric analysis of scientific publications on waterpipe (narghile, shisha, hookah) tobacco smoking during the period 2003-2012. Tobacco Induced Diseases, (12),7 2-6. DOI:10.1186/1617-962512-7 